\begin{tabular}{|r|r|}
\hline p-ISSN 1858-1048 \\
e-ISSN 2654-9247
\end{tabular}

\title{
PENGARUH JUMLAH USAHA MIKRO KECIL MENENGAH DAN JUMLAH TENAGA KERJA UMKM TERHADAP SUMBANGAN PRODUK DOMESTIK BRUTO UMKM PERIODE TAHUN 1997 - 2016
}

\author{
Oleh: \\ Cecep Sidin'1), Miralda Indiarti2) \\ cecep_sidin@yahoo.co.id ${ }^{1}$, miralda89@yahoo.com ${ }^{2}$ ) \\ Sekolah Tinggi Ilmu Ekonomi IPWI Jakarta1,2)
}

\begin{abstract}
ABSTRAK
Maksud dari penelitian ini, membuktikan adanya pengaruh varibel bebas pertama, Jumlah Usaha Mikro Kecil Menengah (UMKM) dan variabel bebas kedua Jumlah Tenaga Kerja UMKM terhadap variabel terikat Sumbangan Produk Domestik Bruto (PDB) UMKM sebagai salah satu indikator Perekonomian Indonesia periode tahun 1997-2016. Dengan program SPSS versi 24 didapat hasil penelitian bahwa determinasi koefisien nilai $R$ sebesar 0,767 dan sedangkan nilai $R$ Square sebesar 0,588 atau 58,8\%, hal ini dapat dinyatakan dengan hasil analisa secara bersama-sama variabel independen Jumlah UMKM (X1) dan Jumlah Tenaga Kerja UMKM (X2) terhadap variabel dependen Sumbangan Produk Domestik Bruto (PDB) UMKM (Y) memiliki nilai positif dan tingkat persentase pengaruhnya tinggi yaitu sebesar 58,8\% dan sisanya sebesar 41,2\% disebabkan oleh faktor-faktor lain. Berdasarkan pada hasil uji ANOVA didapat nilai ratio - F sebesar 12,126 dengan signifikansi sebesar 0,001 karena nilai tersebut lebih kecil dari level signifikansi a 0,01 maka Ho ditolak. Dapat dikatakan variabel Jumlah UMKM (X1) dan Jumlah Tenaga Kerja UMKM (X2) secara bersama-sama berpengaruh signifikan dengan variabel Sumbangan PDB UMKM (Y), Hipotesis alternatif (Ha) terbukti.
\end{abstract}

Kata Kunci: wirausaha, UMKM, tenaga kerja, $P D B$

\section{PENDAHULUAN}

Kehidupan perekonomian yang semakin banyak tantangan dan tuntutan global membuat kebanyakan rumah tangga di Indonesia membutuhkan usaha kecil untuk menambah penghasilan keluarga, dimana hanya mengandalkan gaji atau penghasilan bulanan kepala keluarga. Istri dan ibu dalam rumah tangga harus mengelola penghasilan keluarga yang kadang sudah tidak mencukupi lagi terhadap kebutuhan keluarga di masa sekarang ini. Situasi ini menimbulkan ide membuat usaha keluarga yang dengan modal relatif sedikit dan tidak perlu persyaratan administratif. Tidak heran, kebanyakan ibu rumah tangga yang mengelola usaha mikro kecil ini. Usaha mikro kecil ini relatif bisa dikerjakan di rumah, tidak menganggu pekerjaan rutin rumah tangga dan masih tetap bisa mengasuh anak tapi sekaligus menambah penghasilan keluarga. Usaha rumahan ini dimasukkan dalam kategori Usaha Mikro Kecil dan Menengah (UMKM). 
Di Indonesia, Usaha Kecil Menangah (UKM) adalah tulang punggung ekonomi Indonesia. Pada tahun 2011, jumlah UKM mencapai 52 juta. UKM di Indonesia sangat penting bagi ekonomi karena menyumbang $60 \%$ dari PDB dan menampung 97\% tenaga kerja. Tetapi akses ke lembaga keuangan sangat terbatas baru $25 \%$ atau 13 juta pelaku UKM yang mendapat akses ke lembaga keuangan. Pembinaan UKM dikelola oleh Dinas Koperasi dan UKM, pada masingmasing Provinsi atau Kabupaten/Kota.

Usaha Kecil Menengah terbukti, mampu menghadapi krisis ekonomi dan memperkecil angka pengangguran yang merupakan masalah krusial perekonomian Indonesia. Karena UMKM tidak membutuhkan bahan baku impor, tidak membutuhkan modal besar dan mampu menampung pengangguran dalam menjalankan usahanya. Sehingga tidak terpengaruh pada kenaikan kurs dan tingkat suku bunga dari dunia luar termasuk Negara-negara maju. UMKM diberi fasilitas, supaya bisa mengekspor barang hasil produksinya ke pasar internasional bersaing dengan produk internasional sudah terkenal sekalipun. Produk UMKM ini dianggap mempunyai keunggulan mutlak (Absolute advantage) yang tidak dimiliki oleh negara lain, sehingga produk tersebut dicari-cari orang dan laku di pasaran internasional. Seperti produk batik, produk kerajinan dan ukiran kayu dari Bali dan Jepara, produk kerajinan rotan, produk kopi dari beberapa daerah di Indonesia, produk komoditi jagung, bumbu-bumbu dapur dan produk kerajinan tangan lainnya.

\section{TUJUAN PENELITIAN}

Penelitian ini untuk membuktikan adanya pengaruh varibel bebas pertama Jumlah Usaha Mikro Kecil Menengah (UMKM) dan variabel bebas kedua Jumlah Tenaga Kerja UMKM terhadap variabel terikat Sumbangan Produk Domestik Bruto (PDB) UMKM sebagai salah satu indikator Perekonomian Indonesia periode tahun 1997-2016.

\section{TELAAH LITERATUR DAN PENGEMBANGAN PROPOSISI/HIPOTESIS \\ Sumbangan Produk Domestik Bruto (PDB) UMKM}

Produk Domestik Bruto merupakan nilai keseluruhan semua barang dan jasa yang diproduksi dalam wilayah tersebut pada jangka waktu tertentu (per tahun). PDB memasukkan pendapatan faktor produksi dari luar negeri yang bekerja di negara tersebut.

PDB dihitung memakai dua pendekatan, pendekatan pengeluaran dan pendekatan pendapatan. Rumus umum untuk PDB dengan pendekatan pengeluaran adalah:

$$
\mathrm{PDB}=\mathrm{C}+\mathrm{I}+\mathrm{G}+(\mathrm{X}-\mathrm{M})
$$

Keterangan :

$$
\begin{aligned}
\mathrm{C}= & \text { konsumsi adalah pengeluaran yang } \\
& \text { dilakukan oleh rumah tangga, } \\
\mathrm{I}= & \text { investasi oleh sektor usaha, } \\
\mathrm{G}= & \text { pengeluaran pemerintah oleh } \\
& \text { pemerintah, dan } \\
\mathrm{X}= & \text { ekspor dan } \\
\mathrm{M}= & \text { impor } \\
& \text { Sedangkan pendekatan pendapatan }
\end{aligned}
$$
menghitung pendapatan yang diterima faktor produksi. PDB terdiri dari sewa, upah dan bunga laba (Tulus T. H. Tambunan, 2016:48).

Secara teori, PDB dengan pendekatan pengeluaran dan pendapatan harus menghasilkan angka yang sama. Karena dalam praktik menghitung PDB dengan pendekatan pendapatan belum bisa dilakukan, maka yang sering digunakan pendekatan pengeluaran.

\section{Usaha Mikro Kecil Menengah (UMKM)}

Wiraswasta adalah orang yang memiliki sifat-sifat keberanian, keutamaan, keteladanan dalam mengambil resiko yang bersumber pada kemampuan sendiri. Wiraswasta tidak mampu mengembangkan visi usaha, daya inovasi dan kreatifitas. Sedangkan Wirausaha (Entrepreneur) adalah orang yang kreatif dan inovatif serta mampu mewujudkannya untuk peningkatan kesejahteraan diri, masyarakat dan lingkungannya. Seorang wirausaha memiliki beberapa karakteristik, yaitu kerja keras, tidak mudah menyerah, ulet 
dan rajin dalam berusaha, selalu mencari peluang dan tantangan baru, mengejar peluang yang dinilai paling potensial, disiplin dan jujur, selalu berinovasi dan kreatif, serta bertanggung jawab penuh terhadap pengambilan keputusan dan kelangsungan usahanya (Rambat Lupiyoadi, 2004:3).

Usaha Kecil dan Menengah disingkat UKM adalah sebuah istilah yang mengacu ke jenis usaha kecil yang memiliki kekayaan bersih paling banyak Rp.200.000.000 tidak termasuk tanah dan bangunan tempat usaha. Menurut Keputusan Presiden RI no. 99 tahun 1998 pengertian Usaha Kecil adalah "Kegiatan ekonomi rakyat yang berskala kecil dengan bidang usaha yang secara mayoritas merupakan kegiatan usaha kecil dan perlu dilindungi untuk mencegah dari persaingan usaha yang tidak sehat."

Di Indonesia,

beberapa pengklasifikasian UMKM dari beberapa perspektif atau pendekatan yang dilakukan oleh lembaga atau instansi bahkan undang-undang. Menurut Undang-Undang No. 20 Tahun 2008 mengenai UMKM memberikan pengertian dan klasifikasi berdasarkan aset dan omset tiap skala usaha sebagai berikut:

Tabel 1

Klasifikasi Usaha

\begin{tabular}{|c|c|c|}
\hline \multirow[b]{2}{*}{$\begin{array}{l}\text { Skala } \\
\text { Usaha }\end{array}$} & \multicolumn{2}{|c|}{ Kriteria } \\
\hline & $\begin{array}{c}\text { Kekayaan } \\
\text { Bersih/Aset } \\
\text { (tidak } \\
\text { termasuk } \\
\text { tanah dan } \\
\text { bangunan } \\
\text { tempat } \\
\text { usaha) }\end{array}$ & $\begin{array}{c}\text { Hasil } \\
\text { Penjualan/Omset }\end{array}$ \\
\hline $\begin{array}{l}\text { Usaha } \\
\text { Mikro }\end{array}$ & $\begin{array}{l}\text { Maksimal } \\
\text { Rp50 juta }\end{array}$ & $\begin{array}{c}\text { Maksimal Rp300 } \\
\text { juta }\end{array}$ \\
\hline $\begin{array}{l}\text { Usaha } \\
\text { Kecil }\end{array}$ & $\begin{array}{l}\text { > Rp50 juta- } \\
\text { Rp500 juta }\end{array}$ & $\begin{array}{l}\text { > Rp300 juta- } \\
\text { Rp2,5 Milyar }\end{array}$ \\
\hline $\begin{array}{c}\text { Usaha } \\
\text { Menengah }\end{array}$ & $\begin{array}{c}>\text { Rp500 } \\
\text { juta-Rp10 } \\
\text { Milyar }\end{array}$ & $\begin{array}{l}\text { > Rp2,5 Milyar- } \\
\text { Rp50 Milyar }\end{array}$ \\
\hline
\end{tabular}

Sedangkan menurut Badan Pusat Statistik (BPS) mengklasifikasikan berdasarkan kuantitas tenaga kerja yang digunakan pada setiap unit usaha yaitu:

1. Usaha Kecil: tenaga kerja 5-19 orang.

2. Usaha Menengah: tenaga kerja 20-99 orang.

Dalam perspektif perkembangan usaha, UMKM diklasifikasikan menjadi empat, yaitu:

- UMKM sektor informal, seperti pedagang kaki lima

- UMKM Mikro, UMKM dengan kemampuan sifat pengrajin namun kurang memiliki jiwa kewirausahaan untuk mengembangkan usahanya.

- UMKM Kecil Dinamis, UMKM yang sudah mampu berwirausaha dengan menjalin kerjasama (menerima pekerjaan sub kontrak) dan ekspor.

Fast Moving Enterprise merupakan UMKM yang sudah berwirausaha dengan cakap dan telah siap bertransformasi menjadi usaha besar (www.bps.go.id).

\section{Tenaga Kerja}

Tenaga kerja merupakan penduduk yang berada dalam usia kerja. Berdasar pada UU No. 13 tahun 2003 Bab I pasal 1 ayat 2 , tenaga kerja adalah setiap orang yang mampu melakukan pekerjaan guna menghasilkan barang atau jasa baik untuk memenuhi kebutuhan sendiri maupun untuk masyarakat. Suatu negara penduduknya dibagi dua kelompok, tenaga kerja dan bukan tenaga kerja. Penduduk tergolong tenaga kerja jika penduduk tersebut telah memasuki usia kerja. Batas usia kerja yang berlaku di Indonesia adalah berumur 15 tahun - 64 tahun.

Berdasarkan kualitasnya, Tenaga Kerja terdiri dari:

1. Tenaga kerja terdidik

Tenaga kerja terdidik adalah tenaga kerja yang memiliki suatu keahlian atau kemahiran dalam bidang tertentu dengan cara sekolah atau pendidikan formal dan nonformal. Contohnya: pengacara, dokter, guru, dan lain-lain. 
2. Tenaga kerja terlatih

Tenaga kerja terlatih, tenaga kerja yang mempunyai keahlian bidang tertentu dengan pengalaman kerja. Tenaga kerja ahli ini dibutuhkan pelatihan berulang-ulang sehingga mampu menguasai pekerjaan tersebut. Contohnya: apoteker, ahli bedah, mekanik, dan lain-lain.

3. Tenaga kerja tidak terdidik dan tidak terlatih

Tenaga kerja tidak terdidik dan tidak terlatih, tenaga kerja kasar hanya mengandalkan tenaga saja. Contoh: kuli, buruh angkut, pembantu rumah tangga, dan sebagainya

\section{Penelitian terdahulu}

Menurut penelitian Mahardea Puspa Senja, Usaha mikro, kecil, dan menengah (UMKM) di Indonesia merupakan industri terbesar dalam jumlah dan kemampuannya dalam menyerap tenaga kerja. Walaupun, ukuran sumbangan terhadap PDB belum cukup tinggi, sektor ini dapat tetap menjadi tumpuan bagi stabilitas ekonomi. Hasil penelitian ini menunjukkan bahwa variabel jumlah unit UMKM dan nilai investasi UMKM mempunyai pengaruh yang positif dan signifikan terhadap pertumbuhan ekonomi di Indonesia, sedangkan variabel tenaga kerja UMKM dan nilai ekspor UMKM tidak berpengaruh terhadap pertumbuhan ekonomi di Indonesia.

\section{Kerangka Pemikiran}

Gambar 1

Kerangka/Konstelasi

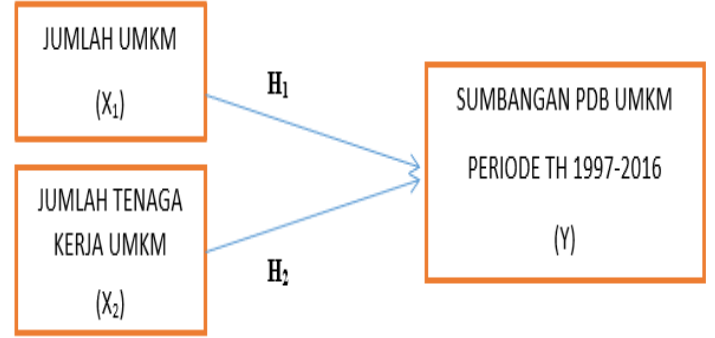

\section{Hipotesis Penelitian}

H1: Jumlah UMKM berpengaruh pada Sumbangan PDB UMKM
H2: Tenaga kerja UMKM berpengaruh pada Sumbangan PDB UMKM

\section{METODE PENELITIAN Sampel penelitian}

Data dalam penelitian ini adalah data time series jumlah UMKM, jumlah tenaga kerja UMKM dan sumbangan produk domestik bruto (PDB) UMKM periode tahun 1997-2016 (data tahunan) yang bersumber dari Kementerian Koperasi dan Usaha Kecil dan Menengah dan Badan Pusat Statistik (BPS) yang berbentuk jurnal tahun 1997-2016.

Jenis data penelitian ini adalah data sekunder berisi informasi jumlah UMKM, jumlah tenaga kerja UMKM dan sumbangan PDB UMKM berasal dari website BPS (www.bps.go.id) dan website Kementerian Koperasi dan Usaha Kecil dan Menengah (www.depkop.go.id).

Populasi penelitian, Perekonomian Indonesia dengan salah satu indikatornya yaitu Sumbangan Produk Domestik Bruto (PDB) UMKM 19972016. Sampel penelitian, Produk Domestik Bruto dapat dikatakan variabel penting dalam ekonomi makro Perekonomian Indonesia periode 19972016 (19 tahun).

\section{Desain Penelitian}

Penelitian ini merupakan penelitian deskriptif analisis dengan pendekatan kuantitatif, data yang diperoleh dari sampel populasi penelitian dianalisis sesuai dengan metode statistik yang digunakan (software SPSS versi 24) dan diinterpretasikan.

Menurut Sugiyono, penelitian deskriptif adalah penelitian dilakukan untuk mengetahui nilai variabel mandiri, satu variabel atau lebih (independen) tanpa membuat perbandingan atau menghubungkan dengan variabel lain (Sugiyono 2003:11). Penelitian kuantitatif, adalah penelitian dengan memperoleh data berbentuk angka atau data kualitatif yang diangkakan (Sugiyono, 2003:14). 
Definisi Operasional dan Pengukuran Variabel Penelitian

Tabel 2

Indikator Variabel Penelitian

\begin{tabular}{|c|c|c|c|c|}
\hline No & Variabel & Alat ukur & Rumus & Referensi \\
\hline 1 & Jumlah UMKM & $\begin{array}{l}\text { Hasil } \\
\text { perhitungan } \\
\text { Depkop dan } \\
\text { BPS }\end{array}$ & - & $\begin{array}{l}\text { www.bps.go,id } \\
\text { www.depkop.go.id }\end{array}$ \\
\hline 2 & $\begin{array}{l}\text { Jumlah Tenaga } \\
\text { Kerja UMKM }\end{array}$ & $\begin{array}{l}\text { Hasil } \\
\text { perhitungan } \\
\text { Depkop dan } \\
\text { BPS }\end{array}$ & - & $\begin{array}{l}\text { www.bps.go,id } \\
\text { www.depkop.go,id }\end{array}$ \\
\hline 3 & $\begin{array}{l}\text { Sumbangan } \\
\text { Produk } \\
\text { Domestik Bruto } \\
\text { (PDB) UMKM }\end{array}$ & $\begin{array}{l}\text { Hasil } \\
\text { perhitungan } \\
\text { Depkop dan } \\
\text { BPS }\end{array}$ & $\mathrm{PDB}=\mathrm{C}+\mathrm{I}+\mathrm{G}+(\mathrm{X}-\mathrm{M})$ & $\begin{array}{l}\text { www.bps.go,id } \\
\text { www.depkop.go.id }\end{array}$ \\
\hline
\end{tabular}

\section{Metode Analisis}

Untuk mengetahui korelasi antara hubungan variabel yang akan dianalisis sesuai dengan tujuan penelitian, dengan bantuan program SPSS versi 24 maka digunakan Regresi Linier berganda

$$
\hat{\mathrm{Y}}=\mathrm{a}_{\mathrm{o}}+\mathrm{a}_{1} \mathrm{UMKMt}+\mathrm{a}_{2} \mathrm{TKt}+\mathrm{Ut}
$$

Keterangan:

$\hat{\mathrm{Y}}=$ Sumbangan PDB UMKM

UMKMt = Jumlah UMKM

TKt $=$ Jumlah Tenaga Kerja

$\mathrm{a}_{\mathrm{o}}=$ Intersep persamaan regresi

$\mathrm{a}_{1} \mathrm{a}_{2}=$ koefisien regresi

$\mathrm{Ut}=$ kesalahan (penganggu)

Persamaan diestimasi dengan program SPSS versi 24 untuk periode tahun 1997 sampai dengan tahun 2016. Alat statistik yang digunakan dalam analisis, selain regresi adalah ANOVA.

\section{HASIL DAN PEMBAHASAN \\ Hasil Penelitian \\ Hasil Uji Multikolonieritas}

Hasil terbesar pada variabel jumlah UMKM yang mempunyai korelasi cukup besar dengan variabel sumbangan PDB UMKM, tingkat korelasinya masih di bawah 95\% maka tidak terjadi multikolonieritas.

\section{Hasil Uji Homoskedastisitas}

Model regresi yang baik, homoskedastisitas atau tidak terdapat heteroskedastisitas. Dalam penelitian ini hasilnya yaitu titik-titik menyebar secara acak serta tersebar baik di atas maupun bawah angka 0 pada sumbu Y. Deteksi ada tidaknya gejala heteroskedastisitas tersebut dilakukan dengan melihat ada tidaknya pola tertentu pada grafik scatterplots di bawah ini.

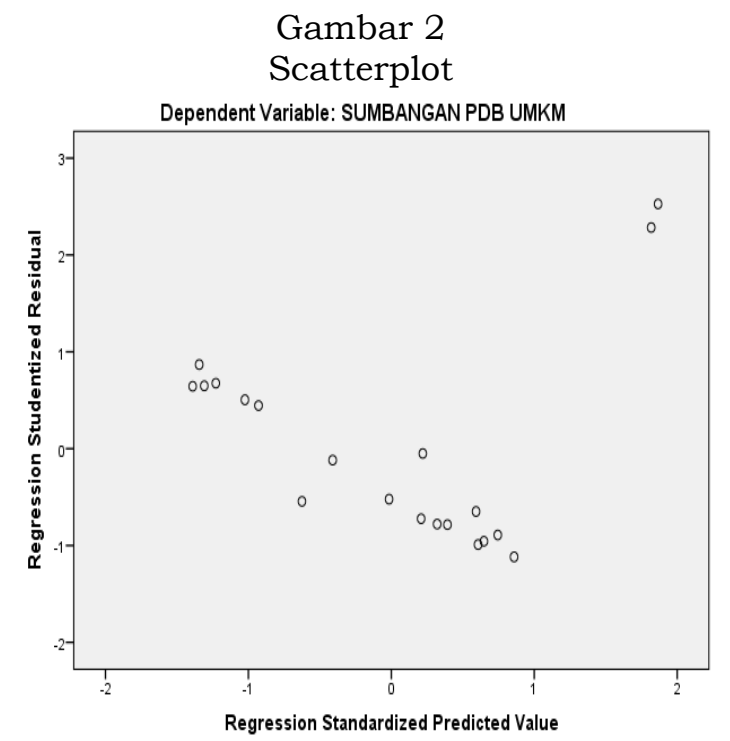

\section{Uji Kelayakan Model}

Tabel 3

Model Summary

\begin{tabular}{|c|c|c|c|c|}
\hline Model & $\mathrm{R}$ & R Square & $\begin{array}{l}\text { Adjusted } \\
\text { R Square }\end{array}$ & $\begin{array}{l}\text { Std. Error of } \\
\text { the Estimate }\end{array}$ \\
\hline 1 & $.767^{a}$ & 0.588 & 0.539 & 920042.22669 \\
\hline
\end{tabular}

Tabel di atas Model Summary yang menghasilkan nilai $R$ sebesar 0,767 menunjukkan hubungan positif yang sangat kuat antara variabel faktor-faktor Independen secara bersama-sama dengan variabel Sumbangan Produk Domestik Bruto (PDB) UMKM, karena koefisien korelasinya mendekati angka 1 atau $100 \%$. Sedangkan nilai $\mathrm{R}$ Square sebesar 0,588 atau $58,8 \%$, hal ini dapat dinyatakan dengan hasil analisa secara bersama-sama variabel independen Jumlah UMKM $\left(\mathrm{X}_{1}\right)$ dan Jumlah Tenaga Kerja UMKM $\left(\mathrm{X}_{2}\right)$ terhadap variabel dependen Sumbangan PDB UMKM (Y) 
memiliki nilai positif dan tingkat persentase pengaruhnya tinggi di atas $50 \%$ yaitu sebesar $58,8 \%$ dan sisanya sebesar $41,2 \%$ disebabkan oleh faktorfaktor lain.

Tabel 4

ANOVA $^{\mathrm{a}}$

\begin{tabular}{|c|c|c|c|c|c|c|}
\hline \multicolumn{2}{|c|}{ Model } & $\begin{array}{l}\text { Sum of } \\
\text { Squares }\end{array}$ & $\mathrm{df}$ & $\begin{array}{l}\text { Mean } \\
\text { Square }\end{array}$ & $\mathrm{F}$ & Sig. \\
\hline 1 & $\begin{array}{l}\text { Regres } \\
\text { sion }\end{array}$ & $\begin{array}{r}20528892 \\
854938.6\end{array}$ & 2 & $\begin{array}{r}102644 \\
484274 \\
69.3\end{array}$ & 12.126 & $.001^{2}$ \\
\hline & $\begin{array}{l}\text { Residu } \\
\text { al }\end{array}$ & $\begin{array}{r}14390120 \\
881252.1\end{array}$ & 17 & $\begin{array}{r}846477 \\
698897 \\
2\end{array}$ & & \\
\hline & Total & $\begin{array}{l}34919013 \\
736190.7\end{array}$ & 18 & & & \\
\hline
\end{tabular}

a. Dependent Variable: SUMBANGAN PDB UMKM

b. Predictors: (Constant), JUMLAH TENAGA KERJA, JUMLAI UMKM

Dari tabel korelasi didapat hasil hubungan antara variabel signifikan terhadap ada yang menunjukkan korelasi yang tinggi dan signifikan yaitu jumlah UMKM. Perincian sebagai berikut:

- Sumbangan Produk Domestik Bruto (PDB) UMKM terhadap Jumlah UMKM korelasi 0,726 dengan taraf signifikan $0,000<0,05$ berarti signifikan,

- Sumbangan Produk Domestik Bruto (PDB) UMKM terhadap Jumlah Tenaga Kerja UMKM korelasi 0,659 dengan taraf signifikan $0,001<0,05$ berarti signifikan.

- Jumlah UMKM terhadap Jumlah Tenaga Kerja UMKM berkorelasi 0,978 dengan taraf signifikan 0,000 $<0,05$ berarti signifikan.

Tabel 5

Correlations

\begin{tabular}{|c|c|c|c|c|}
\hline & & $\begin{array}{c}\text { JUMLAH } \\
\text { UMKM } \\
\end{array}$ & $\begin{array}{c}\text { JUMLAH } \\
\text { TENAGA } \\
\text { KERJA }\end{array}$ & $\begin{array}{c}\text { SUMBANGNN } \\
\text { PDB UMKM }\end{array}$ \\
\hline \multirow[t]{3}{*}{$\begin{array}{l}\text { JUMLAH } \\
\text { UMKM }\end{array}$} & $\begin{array}{l}\text { Pearson } \\
\text { Comelation }\end{array}$ & 1 & $978^{\prime \prime}$ & $.726^{\prime \prime}$ \\
\hline & $\begin{array}{l}\text { Sig. (1n } \\
\text { tailed) }\end{array}$ & & 0.000 & 0.000 \\
\hline & $\mathrm{N}$ & 20 & 20 & 20 \\
\hline \multirow{3}{*}{$\begin{array}{l}\text { JMLAH } \\
\text { TENAGA } \\
\text { KERJ/A }\end{array}$} & $\begin{array}{l}\text { Pearson } \\
\text { Correlation }\end{array}$ & $978^{\prime \prime}$ & 1 & 659 \\
\hline & $\begin{array}{l}\text { Sig. (1- } \\
\text { tailed) }\end{array}$ & 0.000 & & 0.001 \\
\hline & $\mathrm{N}$ & 20 & 20 & 20 \\
\hline \multirow[t]{3}{*}{$\begin{array}{l}\text { SLMBANGAN } \\
\text { PDB UMKM }\end{array}$} & $\begin{array}{l}\text { Pearson } \\
\text { Conrelation }\end{array}$ & $.726^{\prime \prime}$ & $659^{17}$ & 1 \\
\hline & $\begin{array}{l}\text { Sig. (1 } \\
\text { tailed) }\end{array}$ & 0.000 & 0.001 & \\
\hline & $\mathrm{N}$ & 20 & 20 & 20 \\
\hline
\end{tabular}

Berdasarkan hasil regresi diketahui persamaan regresi linear bergandanya sebagai berikut:

$\hat{Y}=-5606750.057+0,308 X_{1}-0,089 X_{2}$

Dapat dijelaskan sebagai berikut:

a. Nilai konstanta intersep sebesar 5606750.057 menyatakan bila tidak terdapat variable Jumlah UMKM dan Jumlah Tenaga Kerja UMKM maka Sumbangan PDB UMKM yang dihasilkan sebesar $\quad-5606750.057$ atau dapat juga dinyatakan bahwa nilai konstanta intersep sebesar 5606750.057 menggambarkan PDB rata-rata jika nilainya nol.

b. Koefisien regresi dari variabel Jumlah UMKM (X1) sebesar 0,308 menyatakan setiap penambahan sebesar satu satuan variabel Jumlah UMKM, akan meningkatkan Sumbangan PDB UMKM sebesar 0,308 dengan anggapan variabel bebas lainnya tetap.

c. Koefisien regresi dari variabel Jumlah Tenaga Kerja UMKM (X2) sebesar -0,089 menyatakan setiap penambahan sebesar satu satuan variable Jumlah Tenaga Kerja UMKM, akan menurunkan Sumbangan PDB UMKM sebesar 0,089 dengan anggapan variabel bebas lainnya tetap.

\section{Pembahasan}

Dari hasil penelitian, Jumlah UMKM dan Jumlah Tenaga Kerja UMKM bersama-sama mempengaruhi Sumbangan Produk Domestik Bruto (PDB) UMKM periode Tahun 1997-2016. Jumlah UMKM dan Jumlah Tenaga Kerja UMKM terdapat korelasi yang sangat tinggi hampir $100 \% \quad(0.978$ dengan sig 0,000 jadi signifikan). Meningkatnya Jumlah UMKM dan Jumlah Tenaga Kerja UMKM secara otomatis meningkatkan Sumbangan PDB UMKM. Sampai sekarang Usaha Mikro, Kecil dan Menengah atau disingkat UMKM memiliki peran penting dan strategis dalam pembangunan ekonomi nasional.

Kementerian Koperasi dan UKM RI melaporkan secara jumlah unit, UMKM terdapat pangsa sekitar 99,99\% $\quad(57,9$ juta unit) dari total keseluruhan pelaku 
usaha di Indonesia (2013), usaha besar hanya sebanyak $0,01 \%$ atau sekitar 5000 unit. UMKM ini dapat menampung 104,6 juta tenaga kerja $(88,9 \%)$, Usaha Kecil 5,57 juta $(4,73 \%)$, dan Usaha Menengah 3,95 juta (3,36\%); sementara Usaha Besar menyerap sekitar 3,54 juta jiwa. Apabila digabungkan, skala kegiatan ekonomi UMKM memberikan kontribusi $60 \%$ terhadap total Pendapatan Domestik Bruto Indonesia. Tahun 2017, PDB Indonesia mencapai Rp 13.600 trilyun. Artinya total pendapatan UMKM sekitar Rp 8.160 trilyun! Usaha Mikro menyumbang sekitar Rp 5000 trilyun/ tahun, Usaha Kecil Rp 1300 trilyun, Usaha Menengah sekitar Rp 1800 trilyun; dan Usaha Besar sekitar Rp 5400 trilyun. Sedang tahun 2018 jumlah pelaku UMKM di Indonesia diperkirakan 58,97 juta oleh Data Badan Perencanaan Pembangunan Nasional, Badan Pusat Statistik, dan United Nation Population Fund.

\section{KESIMPULAN \\ Simpulan}

Dari hasil penelitian dapat disimpulkan bahwa meningkatnya Jumlah UMKM pada dasarnya diterjemahkan sebagai penambahan Sumbangan PDB UMKM berarti meningkatnya pertumbuhan Ekonomi Indonesia.

Sumbangan Produk Domestik Bruto (PDB) UMKM terhadap Jumlah Tenaga Kerja UMKM mempunyai korelasi positif berarti berpengaruh positif pada pertumbuhan Ekonomi Indonesia. Sumbangan Produk Domestik Bruto (PDB) UMKM dipengaruhi secara bersama-sama oleh Jumlah UMKM dan Jumlah Tenaga Kerja UMKM.

\section{Saran}

1. Usaha Mikro Kecil dan Menengah masih perlu dievaluasi dan dibantu pemerintah baik permodalan maupun pengelolaannya (manajemen). Permodalan dengan memberikan kredit usaha kecil dan menengah dari bank-bank Pemerintah sangat membantu permodalan mereka.
2. Sumbangan Produk Domestik Bruto (PDB) UMKM dipengaruhi secara bersama-sama oleh Jumlah UMKM dan Jumlah Tenaga Kerja UMKM. Hasil Penelitian ini mendukung penelitian-penelitan sebelumnya sehingga dapat dijadikan referensi untuk penelitian selanjutnya.

\section{DAFTAR PUSTAKA}

Lupiyoadi, Rambat. 2004. Entrepreneurship form mindset to strategy. Jakarta: Fakultas Ekonomi Universitas Indonesia.

Sugiyono. 2003. Metode Penelitian Administrasi. Bandung: $\quad \mathrm{CV}$ Alfabeta.

Senja, Mahardea Puspa. 2016. Analisis Pengaruh Jumlah UMKM, Jumlah Tenaga Kerja UMKM, Ekspor UMKM dan Investasi UMKM Terhadap Pertumbuhan Ekonomi Indonesia. Semarang: Fakultas Ekonomika dan Bisnis Universitas Diponegoro. https://dokumen.tips /documents/analisis-pengaruhjumlah-umkm-jumlah-tenagakerja-umkm-ekspor-.html

Tambunan, Tulus T. H. 2012. Perekonomian Indonesia: Kajian Teoretis dan Analisis Empiris. Bogor: Penerbit Ghalia Indonesia. https:// 1fitriani.blogspot.com/2016/09 / normal-0-false-false-false-in- $x$ none-x_34.html

https://www.ukmindonesia.id/bacaartikel/62

https://id.wikipedia.org/wiki/Tenaga_ke rja

www.depkop.go.id

www.bps.go.id 